\title{
Bioactivity of Ti6Al4V alloy with bioglass and corrosion protection by silane coating
}

Bioatividade da liga Ti6Al4V com biovidro e proteção a corrosão por revestimento com silano

Bioactividad de la aleación Ti6Al4V con biovidrio y protección contra la corrosión mediante revestimiento de silano

Patrícia Marcolin

ORCID: https://orcid.org/0000-0002-9905-8047 University of Caxias do Sul, Brazil E-mail: pmarcolin@ucs.br

Caroline Olivieri da Silva Frozza ORCID: https://orcid.org/0000-0003-2144-7138 University of Caxias do Sul, Brazil E-mail: cosfrozz@ucs.br

João Antonio Pêgas Henriques ORCID: https://orcid.org/0000-0002-5298-932X University of Caxias do Sul, Brazil E-mail: japhenriques@ucs.br Sandra Raquel Kunst ORCID: https://orcid.org/0000-0002-8060-3981 FEEVALE University, Brazil

E-mail: tessaro.sandra@gmail.com

Murilo Camuri Crovace ORCID: https://orcid.org/0000-0002-6993-6363 Federal University of São Carlos, Brazil E-mail: mcc@ufscar.br

Mariana Roesch Ely ORCID: https://orcid.org/0000-0003-3339-1901 University of Caxias do Sul, Brazil E-mail: mrely@ucs.br

Lucia Vieira

ORCID: https://orcid.org/0000-0002-9354-6533 University of Paraiba Valley, Brazil

E-mail: lucia.vieira@univap.br

María Cristina Moré Farias

ORCID: https://orcid.org/0000-0001-5910-6107 University of Caxias do Sul, Brazil E-mail: mcmfarias@ucs.br

Rosmary Nichele Brandalise ORCID: https://orcid.org/0000-0002-4719-6093 University of Caxias do Sul, Brazil E-mail: rnbranda@ucs.br

\begin{abstract}
The Ti6Al4V alloy is usually employed as a biomaterial, however, when in use, exhibits a few drawbacks such as corrosion, caused by the release of aluminum and vanadium ions besides the bioinert behavior. Bioactive coatings offer a barrier effect and bioactivity, promoting biocompatibility and osseointegration processes. The present work aims to study the biocompatibility behavior of a bioglass-containing silane film deposited on a titanium alloy (Ti6Al4V) substrate. The effect of the surface roughness of the metallic substrate was also evaluated. Film/substrate systems were characterized as their morphological, chemical, physical, electrochemical behavior, and cell cytotoxicity and cell viability. The main results pointed out that silane films augment corrosion resistance of titanium alloy substrates. The biological results indicated a growth of osteoblast cells (MG-63), for all the test conditions. The bioglass film deposited on the ground substrate exhibits the highest cell density.
\end{abstract}

Keywords: Biocompatibility; Bioglass; Corrosion; Silane film; Ti6Al4V.

\section{Resumo}

A liga Ti6Al4V é usualmente empregada como biomaterial, porém, quando em uso, apresenta alguns inconvenientes como a corrosão causada pela liberação de íons alumínio e vanádio além do comportamento bioinert. Os revestimentos bioativos oferecem um efeito de barreira e bioatividade, promovendo processos de biocompatibilidade e osseointegração. O presente trabalho tem como objetivo estudar o comportamento de biocompatibilidade de um 
filme de silano contendo biovidro depositado sobre um substrato de liga de titânio (Ti6Al4V). O efeito da rugosidade superficial do substrato metálico também foi avaliado. Os sistemas filme / substrato foram caracterizados quanto ao comportamento morfológico, químico, físico, eletroquímico e citotoxicidade e viabilidade celular. Os principais resultados apontaram que filmes de silano aumentam a resistência à corrosão de substratos de liga de titânio. Os resultados biológicos indicaram crescimento de células osteoblásticas (MG-63), para todas as condições de teste. O filme de biovidro depositado no substrato moído exibiu a maior densidade celular.

Palavras-chave: Biocompatibilidade; Biovidro; Corrosão; Filme de silano; Ti6Al4V.

\section{Resumen}

La aleación Ti6A14V generalmente se emplea como biomaterial, sin embargo, en la práctica presenta algunos inconvenientes como la corrosión, causada por la liberación de iones de aluminio y vanadio además del comportamiento bioinerte. Los recubrimientos bioactivos ofrecen efecto barrera y bioactividad, lo que favorece los procesos de biocompatibilidad y osteointegración. El presente trabajo tiene como fin estudiar el comportamiento biocompatible de un recubrimiento de silano con biovidrio depositado sobre un sustrato de aleación de titanio (Ti6Al4V). También se evaluó el efecto de la rugosidad superficial del sustrato metálico. Los sistemas recubrimiento/sustrato se caracterizaron en cuanto a sus características morfológicas, químicas, físicas, electroquímicas, citotoxicidad y viabilidad celulares. Los principales resultados obtenidos indicaron que los recubrimientos de silano aumentan la resistencia a la corrosión de los sustratos de la aleación de titanio. Los resultados biológicos obtenidos indicaron un crecimiento de células osteoblásticas (MG-63), para todas las condiciones de ensayo. El recubrimiento de biovidrio depositado sobre el sustrato lijado presenta la mayor densidad celular.

Palabras clave: Biocompatibilidad; Biovidrio; Corrosion; Recubrimiento de silano; Ti6Al4V.

\section{Introduction}

The Ti6Al4V alloy is widely employed as a biomaterial in the orthopedic field. It exhibits higher values of fracture and tensile strength and lower Young's modulus compared to other metallic materials (Chen \& Thouas, 2015; Chiu et al., 2007; Fu et al., 2012). Ti6Al4V alloy has some disadvantages, including the release of aluminum (Al) and vanadium (V) ions as a consequence of corrosion and wear as well as the lack of bioactivity (Chen \& Thouas, 2015; Cremasco et al., 2011; Harada et al., 2016; Punt et al., 2008; Veronesi et al., 2017).

The relative movement between bone and implant surfaces causes severe wear of the metallic material and promotes the release of metallic ions within the human body. Concomitantly, the harsh conditions of the physiological environment can result in metal corrosion. In this case, the corrosion mechanism is characterized by the occurrence of anodic and cathodic processes at metal/solution and oxide/solution interfaces (Mathew et al., 2012; Silva-Bermudez \& Rodil, 2013). Corrosion and wear can cause inflammatory and allergenic reactions in the host body (Ahmed et al., 2016; Ibrahim et al., 2017; RodríguezCano et al., 2013).

The Ti6Al4V alloy exhibits a bioinert behavior when inserted into the human body and hinder the interaction of the implant with bone tissue, making it difficult to form fibrous tissue around the implant. The formation of fibrous tissue around the implant is a fundamental condition for the implant not to come loose. Thus, the material to be employed for bone tissue reconstruction should provide tissue cicatrization, complying with biological requirements such as biocompatibility, biofunctionality, and osteocondutibility (Andrade et al., 2007; Asri et al., 2017; Chen \& Thouas, 2015; Pires et al., 2015; Romagnoli et al., 2013; Su et al., 2018).

The use of protective barrier films has been proposed to increase the corrosion resistance of metallic surfaces. Such films can be deposited by different coating techniques such as physical vapor deposition, electrochemical deposition, plasma spraying, and sol-gel immersion (Aydınoğlu \& Yoruç, 2017; Owens et al., 2016). Sol-gel immersion of alkoxide precursors by dip-coating is considered one of the most promising low-cost methods for the deposition of functional coatings. Among silicon, aluminum, zirconium, and titanium alkoxides, silicon alkoxide has called the attention because they are relatively easy to produce (Owens et al., 2016). Bioactive particles may be incorporated through this process (Aydınoğlu \& Yoruç, 2017; El- 
Ghannam \& Ducheyne, 2017; Pires et al., 2015). Examples of bioactive materials are hydroxyapatite, bioglasses, and vitroceramics (El-Ghannam \& Ducheyne, 2017; Hallab et al., 2004; Pires et al., 2015; Rasouli et al., 2018; Sepulveda et al., 2002).

The topography and chemical composition of implants influence the morphology, the viability, and the proliferation of the cells (Baxter et al., 2002; Rosa et al., 2013). It is believed that cell behavior can be modulated by adjusting the topographic characteristics in micro- and nanometric scales. The diameter of individual cells is typically dozens of micrometers, while the dimensions of the subcellular structure tend to the nanoscale. In this way, the nanometric scale roughness can directly influence cellular interaction (Biggs et al., 2010; Huang et al., 2016; Sjöström et al., 2013).

In this context, the goal of this study was to investigate the corrosion and biocompatibility of a silane film deposited on a Ti6Al4V alloy substrate by dip-coating. Changes in biocompatibility were also evaluated when the silane film was modified by the incorporation of bioglass particles and when the roughness of the metallic substrate was changed by grinding processes. The film biocompatibility was assessed for osteoblastic cells, considering the adhesion ability, viability/proliferation, and cytotoxicity. The present work adopted the case study as a scientific methodology, described by Pereira et al. (2018) and supported by Bacon's fundaments (Köche, 2011). These authors indicate the following steps searching for scientific knowledge: (a) experimentation, (b) formulation of hypotheses based on the analysis of the results obtained from the various experiments, (c) repetition of the experimentation by other scientists, and (d) repetition of the experiment to test the hypotheses, seeking to obtain new data and new evidence to confirm them.

\section{Methodology}

Ti6Al4V alloy sheets supplied by Ti-Brasil Titânio Ltda were used as substrates with an area of $20 \mathrm{~cm}^{2}$ and a thickness of $0.7 \mathrm{~mm}$. This Ti6Al4V alloy complies with the chemical specifications required by the ASTM F1472-14 standard (Ahmed et al., 2016; Rodríguez-Cano et al., 2013). The F18 Bioglass bioactive material was supplied by the Vitreous Materials Laboratory (LaMaV) of the Federal University of São Carlos (UFSCar), Brazil (Zanotto et al., 2013). The film was composed of alkoxides precursors (trimethoxysylylpropyl)methacrylate (MAP) (Sigma-Aldrich, $98 \%$ ) and tetraethoxysilane (TEOS) (Sigma-Aldrich, $99 \%$ ). For the simulation of body conditions, a simulated body fluid (SBF) solution was employed as electrolyte (Kokubo \& Takadama, 2006; Murugan et al., 2015).

Ti6Al4V samples were manually ground with silicon carbide paper starting with 300-grit and following with 600- and 1200-grit. After each grinding step, the metallic substrates were washed with an alkaline detergent. Subsequently, the samples were immersed in an ultrasonic bath of acetone and alcohol (Vetec) for $10 \mathrm{~min}$ in each solvent (Wang et al., 2013). Following the cleaning stage, the substrates were submitted to alkaline treatment in a sodium hydroxide solution $(\mathrm{NaOH})(\mathrm{Neon})$ $0.01 \mathrm{~mol} . \mathrm{L}^{-1}(\mathrm{pH}=11.5)$ for $3 \mathrm{~min}$ at $24{ }^{\circ} \mathrm{C}$ and dried in cold air. This process activates the substrate surface for better film adhesion (Salvador et al., 2018).

The film obtained by the sol-gel process contained the following volumetric proportions (vol.\%): TEOS:sol (1:10); MAP:sol (1.5:10); water:sol (1.5:10); alcohol: sol (6:10) (Certhoux et al., 2013; Salvador et al., 2017). Initially, the sol was prepared at $24{ }^{\circ} \mathrm{C}$ under magnetic agitation. Next, the distilled water was acidified with acetic acid to adjust the pH content to 4.0 (Kunst et al., 2015; Salvador et al., 2018; van Ooij et al., 2005).

Then, the hydrolysis was carried out at $24{ }^{\circ} \mathrm{C}$ for $24 \mathrm{~h}$ without agitation (Kunst et al., 2013). The sol-gel application on the metallic surfaces was conducted by the dip-coating method, keeping the samples in the solution for 5 min. Afterward, the samples were removed from the solution and exposed to air for $1 \mathrm{~h}$ at $24{ }^{\circ} \mathrm{C}$ (Kunst et al., 2015). The film/substrate systems were cured in an oven at $90{ }^{\circ} \mathrm{C}$ for $1 \mathrm{~h}$ (Certhoux et al., 2013; Sakai et al., 2012; Salvador et al., 2017). F18 Bioglass particles 
were also incorporated into the silane film between the drying at $24{ }^{\circ} \mathrm{C}$ and cure at $90{ }^{\circ} \mathrm{C}$ steps. For this purpose, the dissociation of 0.001 g.mL m $^{-1}$ F18 Bioglass was first conducted in alcohol under agitation, according to the ISO 10933-14 standard. The suspension was subsequently dropped on one of the faces of the coated surface using a Pauster pipette (Certhoux et al., 2013; Sakai et al., 2012). In this way, silane films, without (MAP/TEOS) and with the addition of F18 Bioglass particles (MAP/TEOS/F18) were prepared and deposited on Ti6Al4V alloy substrates. Samples sterilization was conducted by Esterilizare Esterilização de Produtos Ltda (Caxias do Sul, RS, Brazil).

The chemical bonding characterization of cured MAP/TEOS and MAP/TEOS/F18 films was conducted by Fourier Transformed Infrared Spectroscopy (Nicolet iS10 - Thermo Scientific - England), employing Attenuated Total Reflectance mode (FTIR-ATR). The infrared spectra were recorded from 4000 to $700 \mathrm{~cm}^{-1}$ at a resolution of $4 \mathrm{~cm}^{-1}$.

The morphology of the uncoated and coated surfaces was evaluated using a Field Emission Gun Scanning Electronic Microscopy (FEGSEM) equipment (Tescan, model Mira3, Czech Republic) and an Energy Dispersion X-Ray Spectroscopy (EDS) detector (Oxford, model X-Max50, Czech Republic) coupled to the FEGSEM equipment. The adhesion of the films to the substrates and the adhesion rate (percent of film area removed) were evaluated by the tape test following the ASTM D3359-09 standard (Salvador et al., 2018), with the aid of the FEGSEM technique.

The surface topography of both the substrates and the film/substrate systems was measured by Atomic Force Microscopy (AFM) (SHIMADZU, model SPM-9500J3, Japan) using non-contact mode and scan size of $(10 \times 10) \mu \mathrm{m}$. The quantification of the roughness irregularities was conducted using the amplitude parameters $R a$ (arithmetic average surface roughness), $R z$ (ten-point height), and $R t$ (maximum height of the profile) (Gadelmawla et al., 2002).

The surface wettability was assessed by contact angle measurements by the sessile drop method using a Yale 3D B-D syringe and SBF solution. Data treatment was conducted with the aid of the Surftens 4.5 Software. Surfaces with a contact angle lower than $80^{\circ}$ were considered hydrophilic and those with contact angle higher than $80^{\circ}$, hydrophobic.

The formation of protective films on the uncoated and coated surfaces was studied by Open Circuit Potential (OCP) measurements carried out in a potentiostat/galvanostat (IviumStat of Ivium Technologies, software IviumSoft, Netherlands). A conventional three-electrode cell was used to monitor the evolution of the OCP values as a function of time, which consisted of the sample (working electrode), the saturated calomel reference electrode (SCE), and the platinum counter electrode. The measurements were carried out in the absence of agitation at $24{ }^{\circ} \mathrm{C}$ with SBF as the electrolyte (Salvador et al., 2018). The evolution of OCP values was monitored during the first hour of immersion. OCP curves were obtained at $1 \mathrm{mV} \cdot \mathrm{s}^{-1} \mathrm{scanning}$ rate by sweeping the potential from $200 \mathrm{mV}$ below to $600 \mathrm{mV}$ above with respect to the open circuit potential.

The biological properties of the samples were evaluated considering cell adhesion ability, viability/proliferation, and cytotoxicity. MG-63 osteoblastic cells were used for these analyses and were acquired from the Bank of Cells of Rio de Janeiro from ATCC. The samples were first exposed to a cell Dulbecco's Modified Eagle's medium (DMEM) according to ISO 1099312 standard procedures (Savaris et al., 2016). The extraction solution was prepared using the samples $\left(6.0 \mathrm{~cm}^{2} \cdot \mathrm{mL}^{-1}\right)$ in DMEM culture medium supplemented with $10 \%$ fetal bovine serum (FBS) and $1 \%$ penicillin/streptomycin (P/S). The culture medium was placed in contact with the plates for $24 \mathrm{~h}$ at $37^{\circ} \mathrm{C}$ in a $5 \% \mathrm{CO}_{2}$ humidified atmosphere to obtain the extraction.

MG-63 cells were seeded in 6-well plates at a density of $1.5 \times 10^{5}$ cells with $2000 \mu \mathrm{L}$ of DMEM culture medium supplemented with $10 \% \mathrm{FBS}$ and $1 \% \mathrm{P} / \mathrm{S}$ on the samples for 1 and 7 days, respectively. Cells were then fixed with a $3 \%$ glutaraldehyde solution in PBS (v/v) for 15 min, followed by a dehydration process with 30, 50, 70, 90, and $100 \%(\mathrm{v} / \mathrm{v})$ ethanol for $10 \mathrm{~min}$. Afterward, the samples were kept in a desiccator until the biological analysis was performed. The samples were coated with gold in sputtering equipment and then examined by FEGSEM in high vacuum mode at a maximum beam voltage of $15 \mathrm{kV}$. 
For the cell viability MTT test, MG-63 cells were seeded at a density of $1.5 \times 10^{4}$ cells.mL ${ }^{-1}$ in $100 \mu \mathrm{L}$ of DMEM culture medium supplemented with $10 \% \mathrm{FBS}$ and $1 \% \mathrm{P} / \mathrm{S}$. After $24 \mathrm{~h}$, the cells were treated with the extract solution of the samples for 1 and 7 days, respectively. DMEM was used as the negative control, and $5 \%$ dimethyl sulfoxide (DMSO) was used as the positive control. All samples were incubated at $37{ }^{\circ} \mathrm{C}$ in a humidified atmosphere with $5 \% \mathrm{CO}_{2}$. The culture medium was removed, and $1.0 \mathrm{mg} . \mathrm{mL}^{-1}$ of 3-(4,5-dimethylthiazol-2-yl)-2,5-diphenyltetrazolium bromide in FSB-free medium and $\mathrm{P} / \mathrm{S}$ was added to the wells. The samples were incubated at $37{ }^{\circ} \mathrm{C}$ for $2 \mathrm{~h}$ in a humidified atmosphere with $5 \% \mathrm{CO}_{2}$. MTT solution was withdrawn, and the formazan crystals were dissolved in $100 \mu \mathrm{L}$ of DMSO. Spectrophotometric measurements at $570 \mathrm{~nm}$ were conducted on a microplate reader (Max190 spectra, Molecular Devices, USA), and the results were expressed as percent viability. The absorbance of the negative control represented $100 \%$ viability, and values for the treated cells were calculated as a percentage of the control.

A direct method to investigate apoptosis events was conducted by dual staining technique using acridine orange and ethidium bromide in 6 well plates. The samples $\left(20 \mathrm{~cm}^{2}\right)$ with and without coating were arranged in the different wells (Liang et al., 2014). MG-63 cells at a density of $1.5 \times 10^{5}$ cells/well were then seeded in $2000 \mu \mathrm{L}$ of DMEM culture medium supplemented with $10 \%$ fetal bovine serum and $1 \% \mathrm{P} / \mathrm{S}$, followed by incubation at $37{ }^{\circ} \mathrm{C}$ in $5 \% \mathrm{CO}_{2}$, for 1 and 7 days. The culture medium was then washed with PBS with acridine orange $\left(100 \mu \mathrm{g} \cdot \mathrm{mL}^{-1}\right)$ and ethidium bromide $\left(100 \mu \mathrm{g} \cdot \mathrm{mL}^{-1}\right)$ dye staining technique. Cells were counted using a fluorescence microscope at $100 \times$ magnification.

Statistical significance was assessed using the one-way analysis of variance (ANOVA) with the multiple mean comparison test (Turkey) to evaluate statistical differences in the case of normal distribution. Significance was accepted for $\mathrm{p}<0.05$ using the Statistical Package for Social Sciences (SPSS, version 19.0) software for Windows.

\section{Results and Discussion}

Figure 1 shows the FTIR spectra of cured and uncured MAP/TEOS and MAP/TEOS/F18 films. The FTIR technique makes it possible to evaluate the functional groups present in each sample and, in this study, also to evaluate the cure promoted in the film. The curing process of silane films is essential to avoid the migration of aluminum and vanadium ions from the metallic substrate to the body fluid. The observed bands for each functional group numbered from 1 to 8 can also be seen (Kurella \& Dahotre, 2005; Liang et al., 2014). A broad absorption band related to the $-\mathrm{OH}$ group can be seen at $3445 \mathrm{~cm}^{-1}(1)$, which is derived from the non-condensed silanol groups ( $\mathrm{Si}-\mathrm{OH}$ ) during the curing step of the films. The $1730 \mathrm{~cm}^{-1}$ (3) band represents the $\mathrm{C}=\mathrm{O}$ functional group originated from the acetic acid used to acidify the distilled water used for preparing the sol-gel. The band between 1130 and $1043 \mathrm{~cm}^{-1}$ (6) is assigned to the Si-O-Si bond. 
Figure 1. FTIR spectra of the uncured and cured hybrid films.

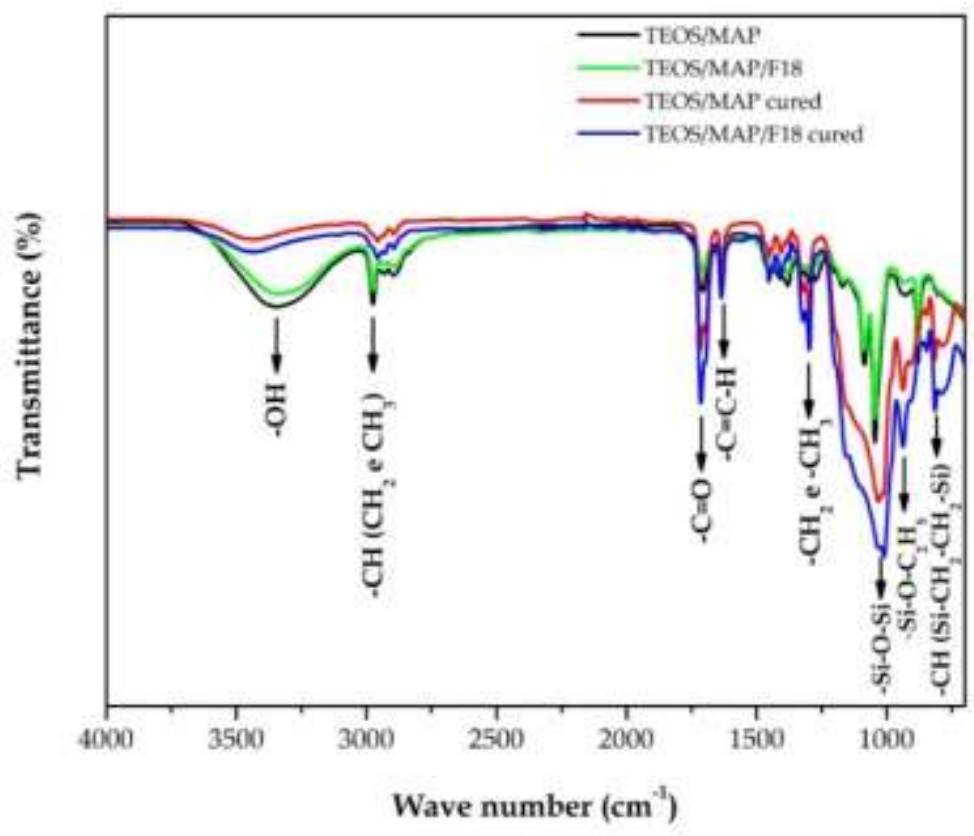

Source: Authors.

In comparison to the cured films, the band (1) in IR spectra of the uncured films exhibits higher intensity, whereas the band (6) shows a lower intensity. These band features confirm, respectively, that the uncured films did not yet undergo the condensation process and that crosslinking between silane molecules effectively occurred during film condensation in the curing process at $90{ }^{\circ} \mathrm{C}$ (Liang et al., 2014; van Ooij et al., 2005). The crosslinking process is responsible for forming a network of Si-O-Si siloxane chains, which results in a silane film with enhanced densification, low permeability, and barrier properties (De Graeve et al., 2007; Romano et al., 2011; van Ooij et al., 2005).

Comparing the IR spectra of the cured films (red and blue lines), the intensity of the band (6) of the bioglasscontaining cured film appears higher than that of the bioglass-free cured film, which relates to the contribution of Si-O-Si stretch coming from the bioglass particles added to the silane film (Chen \& Thouas, 2015; Sepulveda et al., 2002).

Typical FEGSEM micrograph images of the uncoated and coated surfaces are shown in Figure 2. The grinding process creates a uniform distribution of sites on the surface that promotes the mechanical anchoring of coatings. Microcavities and microcracks can be observed on the surface of the as-received Ti6Al4V substrate [Figure 2(a)], which were probably originated from the rolling process. The surface of the ground metallic substrate [Figure 2(b)] exhibited longitudinal and parallel grooves in the grinding direction, which indicates a surface with a more controlled roughness and more uniform as compared with that of the as-received titanium alloy. 
Figure 2. FEGSEM for all the samples; (a) TS/B, (b) TS/G, (c) TS/BC, (d) TS/GC, (e) TS/BCF18, (f) TS/GCF18.
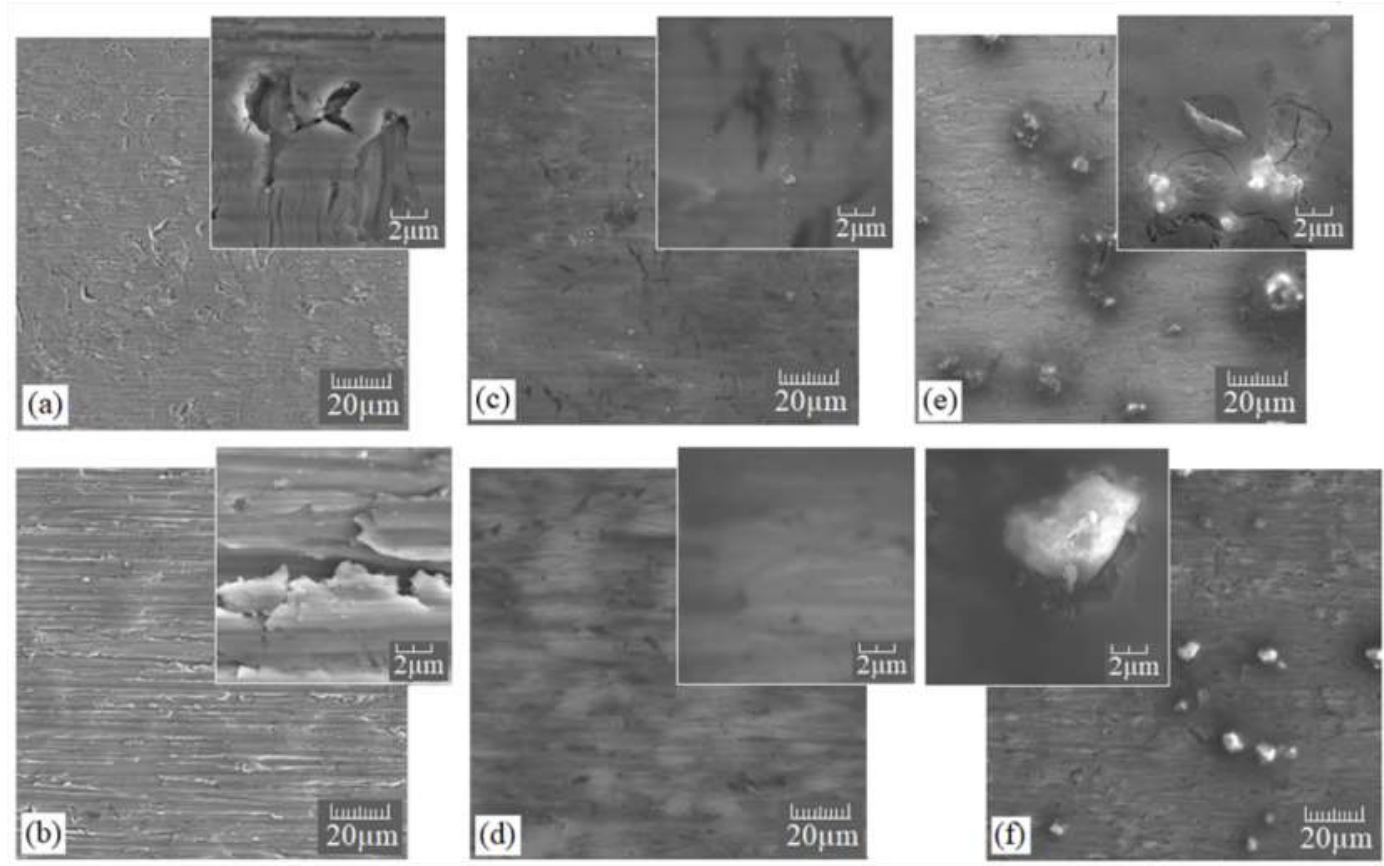

Source: Authors.

The MAP/TEOS films deposited on the metallic substrates seemed thin since the surface irregularities (grinding grooves) of the metallic substrates were still visible from the observation of Figure 2(c,d). Moreover, light and dark regions can be observed, which can be attributed to the variation in film thickness (Salvador et al., 2018). The dark regions corresponded to the microcavities and grooves regions observed on the surface of the metallic substrate, where there was probably more film accumulation (Zhao et al., 2017).

Figure 2(e,f) shows the surface morphology of the MAP/TEOS/F18 films where it is possible to notice dark regions located at the perimeter of the F18 particles, which can be associated to the affinity between the silicon-containing F18 Bioglass particles and the silane film. However, microcracks were observed at the dark regions of the bioglass-containing film deposited on the as-received metallic substrate [Figure 2(e)], which can be associated with the mechanical anchorage of the film in the substrate. When compared with the TS/GCF18 sample, the TS/BCF18 sample, i.e., the as-received substrate, coated with MAP/TEOS/F18 had a smoother surface with less anchoring spots, which might have favored the nucleation and propagation of microcracks in the regions where the bioglass-containing silane film was thicker. Thus, it should be understood that a surface with controlled and uniform roughness, such as the ground one, provides anchoring spots that promote the adhesion of the film to the substrate (Kurella \& Dahotre, 2005; Shoucheng et al., 2018).

Table 1 shows the results of $R a, R z$, and $R t$ roughness parameters for the six samples, including the uncoated asreceived bare and after grinding Ti6Al4V alloy, and the MAP/TEOS and MAP/TEOS/F18 coated. The grinding process significantly increased the asperities amplitude of the substrate since, for example, $R a$ value increased from $7.60 \mathrm{~nm}$ for the asreceived substrate to $14.07 \mathrm{~nm}$ for the ground substrate. The ground substrate coated with the MAP/TEOS film had a $R a$ roughness $(11.30 \mathrm{~nm})$ lower than that of the uncoated ground sample $(14.07 \mathrm{~nm})$ and higher than the as-received coated substrate $(10.12 \mathrm{~nm})$. This behavior also agrees with the FEGSEM analysis of the coated ground surface [Figure 2(d)], which appeared smother in comparison with the uncoated ground surface [Figure 2(b)], indicating that the MAP/TEOS film effectively covered the sample surface. 
Table 1. Values of roughness parameters $R a, R z$ and $R t$, and contact angle of the samples.

\begin{tabular}{|c|c|c|c|c|c|}
\hline Sample code & Surface treatment & $R a(\mathrm{~nm})$ & $R z(\mathbf{n m})$ & $R t(\mathbf{n m})$ & Contact angle $\left({ }^{\circ}\right)$ \\
\hline $\mathrm{TS} / \mathrm{B}$ & $\begin{array}{l}\text { As-received bare Ti6Al4V } \\
\text { alloy }\end{array}$ & $7.60 \pm 0.01$ & $180.94 \pm 0.01$ & $385.62 \pm 0.03$ & $61.7 \pm 0.8$ \\
\hline $\mathrm{TS} / \mathrm{G}$ & Grinding & $14.07 \pm 0.03$ & $303.68 \pm 0.85$ & $632.97 \pm 0.54$ & $60.3 \pm 0.6$ \\
\hline $\mathrm{TS} / \mathrm{BC}$ & Coating & $10.12 \pm 0.01$ & $277.76 \pm 0.65$ & $527.38 \pm 0.35$ & $72.3 \pm 0.8$ \\
\hline $\mathrm{TS} / \mathrm{GC}$ & Grinding + Coating & $11.30 \pm 0.02$ & $419.22 \pm 0.74$ & $821.90 \pm 0.45$ & $74.5 \pm 0.6$ \\
\hline TS/BCF18 & Coating + F18 & $16.61 \pm 0.03$ & $739.15 \pm 0.79$ & $1472.47 \pm 0.58$ & $58.7 \pm 0.6$ \\
\hline TS/GCF18 & Grinding + Coating + F18 & $20.71 \pm 0.04$ & $763.85 \pm 0.76$ & $1508.44 \pm 0.62$ & $55.4 \pm 0.9$ \\
\hline
\end{tabular}

Source: Authors.

For the substrates coated with the MAP/TEOS/F18 film, it can be verified that the $R a$ amplitude roughness parameter increased from $16.61 \mathrm{~nm}$ to $20.71 \mathrm{~nm}$ (Table 1), as a result of the grinding stages in the substrate surface. It is also possible to imply from Table 1 that the Bioglass F18 particles, observed in the FEGSEM micrographs [Figure 2(e, f)], increased the roughness of the film for the two substrate conditions.

Under a biological point of view, studies have reported that roughness is a key factor for bioactivity since cells require anchoring spots at the surface of the implants to start their proliferation (Slepička et al., 2017). According to the obtained results, the arithmetic average surface roughness of all the samples ranged from $7.60 \mathrm{~nm}$ to $20.71 \mathrm{~nm}$. Nanometric scale structures can modulate cell behavior in vivo since the subcell structures - including elements of the cytoskeleton, transmembrane proteins, and filopodia - tend to the nanometric scale. In this way, extracellular support tissues also typically present a complex signal network in the nanometric scale, made up of a complex mixture of nanometric sized (5-200 nm) pits, grooves, pores, protrusions, and fibers, suggesting that the nanoscale roughness has a promising role in cellular interaction. In this context, a few studies report that protrusions in the range from $10 \mathrm{~nm}$ to $350 \mathrm{~nm}$ and $R a$ between $4 \mathrm{~nm}$ and $60 \mathrm{~nm}$ provide suitable bio-fixation sites and, therefore, were qualified as possible promising ranges for cell viability (Hotchkiss et al., 2016; Huang et al., 2016; Rosa et al., 2013; Zareidoost et al., 2012).

Figure 3 shows the FEGSEM micrographs for the MAP/TEOS and MAP/TEOS/F18 coated surfaces submitted to the adhesion test. As shown below, adhesion test also confirms the positive effect of grinding process and its correlation with adhesion of the silane film to the metallic substrate. Adhesion was classified according to the percentage of film area removed (ASTM D3359-09 standard). The detachment of small flakes of the film from the as-received titanium alloy substrate along the edges of the cut, can be observed in Figure 3(a). For this sample, the film area removed was estimated as $7 \%$, approximately, and, according to the ASTM D3359-09 standard, the film adhesion was qualitatively classified as a 3B scale (5 - 15\% area removed). The adhesion was higher for the film deposited on the ground substrate [Figure 3(b)], which was classified as 4B (less than $5 \%$ of the area removed). 
Figure 3. Adhesion test. FEGSEM image and EDS mapping showing Si element for the four film/substrate systems (a) TS/BC, (b) TS/GC, (c) TS/BCF18, (d) TS/GCF18.
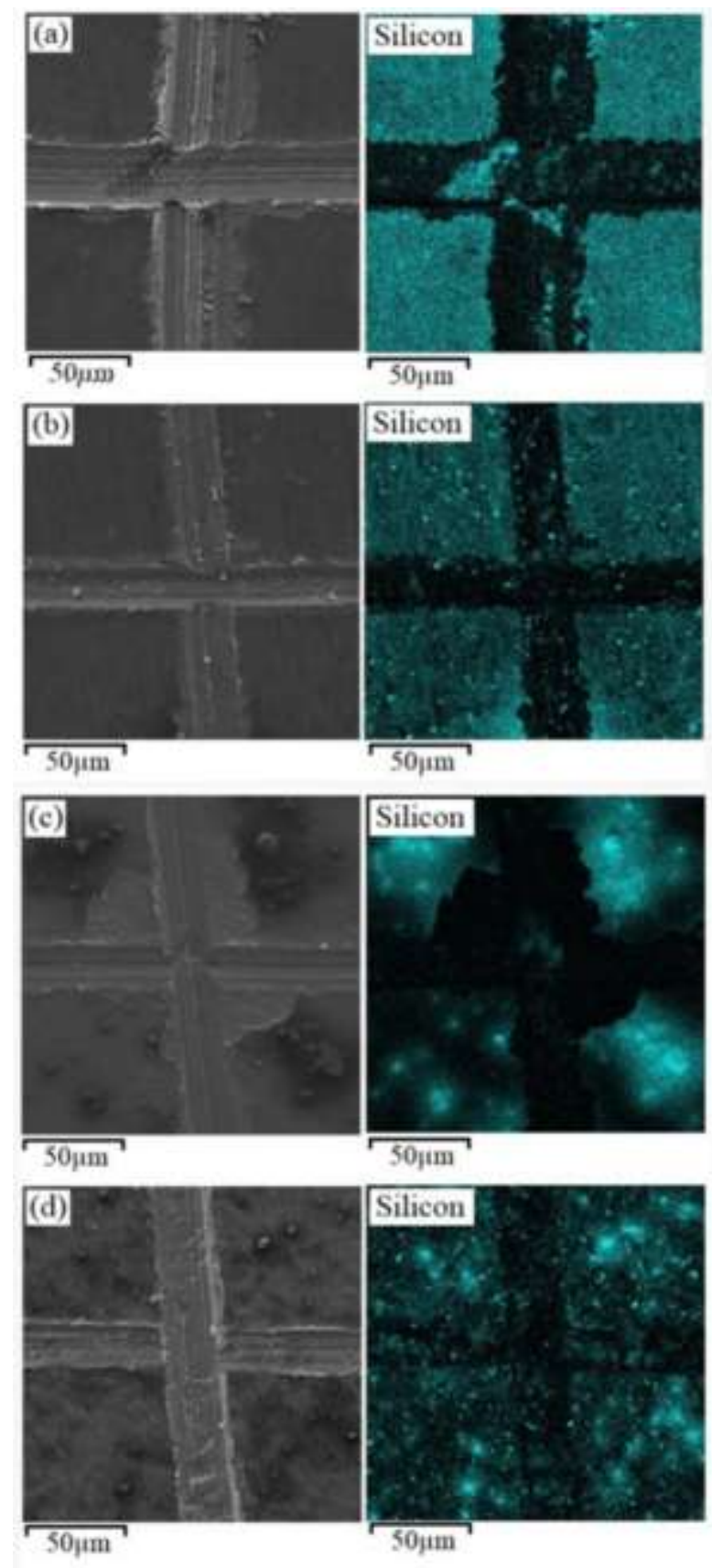

Source: Authors.

For the MAP/TEOS/F18 film/substrate systems, Figure 3(c,d) indicated that the bioglass particles reduced the film adhesion to the as-received and ground substrates. It is also possible to observe that the film deposited on the as-received substrate detached like flakes over a larger area, which suggested a 2B adhesion scale (15\% - $35 \%)$. On the other hand, grinding the substrate offered an enhanced adhesion of the MAP/TEOS/F18 film since the percentage of film area removed was lower (7\%, approximately, 3B scale). The higher adhesion of the MAP/TEOS and MAP/TEOS/F18 films on the ground metallic substrate can be related to the fact that grinding may have increased the number of anchoring spots by increasing the high of peaks and depth of valleys in the roughness profile (Kurella \& Dahotre, 2005; Shoucheng et al., 2018; Wen-Cheng \& 
Ko, 2013). In fact, the measured values of $R z(763.85 \mathrm{~nm})$ and $R t(1508.44 \mathrm{~nm})$ roughness parameters for the ground MAP/TEOS/F18 coated sample were higher than for the as-received coated sample, with $R z=739.15 \mathrm{~nm}$ and $R t=1472.47 \mathrm{~nm}$.

Figure 3 also exhibits the EDS mapping of silicon element, complementing the adhesion test results. Figure 3(a,b) shows that the cut region resultant from the adhesion test appears black, and the original coated surface appears like a deep blue-green color that corresponds to silicon element EDS mapping. This result indicates that the cut region of the adhesion test scarcely contained silicon element and, hence, was a lack of film, confirming the occurrence of the MAP/TEOS film detachment. Additionally, it can also be verified that bioglass addition enlarges film flaking, as shown in EDS silicon element mapping shown in Figure 3(c).

Table 1 also shows the contact angle of the film/substrate systems. All the samples had a contact angle lower than $90^{\circ}$, which characterized such systems as hydrophilic surfaces (Kota et al., 2014; Quéré, 2008). Hydrophilic coatings are suitable for cell growth conditions (Pandiyaraj et al., 2010). Despite the significant variation in the surface roughness of the metallic substrate after grinding, this roughening process did not influence the surface wettability result, as can be observed in Table 1 . Moreover, there was no meaningful change in contact angles among as-received and roughened coated surfaces. Changes in contact angles were thought to be attributable to chemistry, roughness, and nanostructural characteristics of the surfaces (Chowdhury et al., 2017; Hotchkiss et al., 2016).

The hydrophilic character observed for the as-received and ground substrates may be related to hydroxyls on the titanium dioxide passive film spontaneously formed on the surface of the Ti6Al4V alloy (Tengvall \& Lundström, 1992). The negative charge of the hydroxyl groups can promote several chemical interactions between the surface and the SBF drop, such as hydrogen and Van der Waals bonds, resulting in a higher surface hydrophilia (Kuscer et al., 2008).

Hence, the contact angle and the wettability levels changed as the surfaces were coated with MAP/TEOS and MAP/TEOS/F18 films. The MAP/TEOS film/substrate systems exhibited the highest contact angle (lowest wettability) compared with the uncoated metallic substrates and the MAP/TEOS/F18 film/substrate systems. This result may be related to the variation of surface topography, those inherent of peak or asperity heights (surface roughness), and of that arising from the presence of bioglass nanoparticles (protrusion heights) (Chowdhury et al., 2017).

In this sense, the application of bioglass-free films resulted in reduced protrusion heights and increased peak heights that probably promoted an increase in contact angle and hence a reduction in wettability degree. On the other hand, bioglasscontaining films contributed to the introduction of taller and distant protrusions of bioglass particles that may act as reservoirs for a liquid drop, decreasing contact angle values (Chowdhury et al., 2017). The corrosion resistance of the uncoated substrate and film/substrate systems

The analysis of open circuit potential curves of the uncoated samples (Figure 4) showed that the ground sample had more negative potential as compared with the as-received sample, which can be to the protective action of the passive oxide film covering up the surface of the as-received sample (Mohammadloo et al., 2012). The open circuit potential makes it possible to assess corrosion resistance of the uncoated substrate and film/substrate systems. The grinding process could have removed the passive oxide film, exposing the free metallic surface to the attack of the corrosive medium. This corrosion protection loss could explain the increase in the open circuit potential of the ground substrate towards most negative values, which rendered it the most anodic one among all the samples (lest noble). 
Figure 4. Open Circuit Potential curves for the sample.

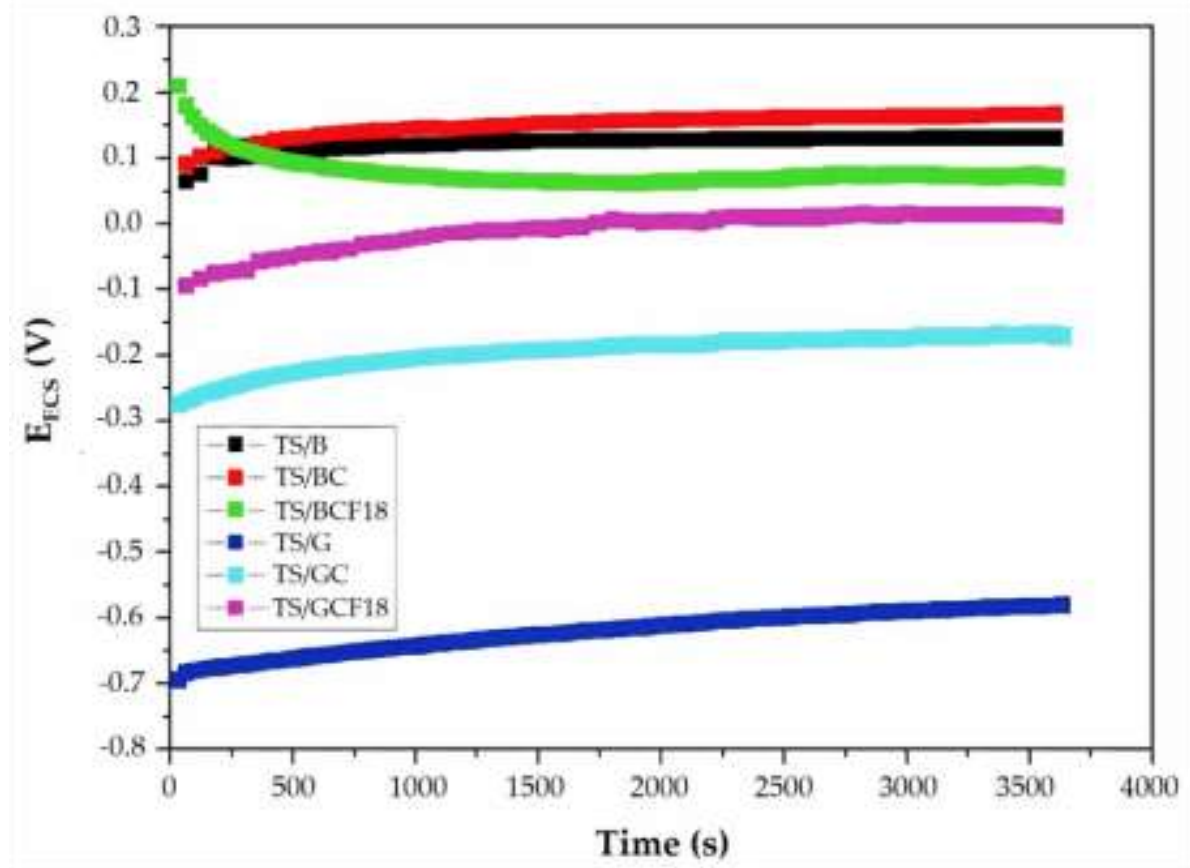

Source: Authors.

The MAP/TEOS film deposited on the as-received substrate exhibited the noblest potential values (Figure 4) that were close to that of the uncoated as-received substrate, pointing out that the MAP/TEOS film preserved the protective character against corrosion of the as-received substrate. This result is in concordance with FEGSEM and contact angle results. The analysis of FEGSEM image shown in Figure 2(d) indicated that the MAP/TEOS film did not have any cracks and, concerning the contact angle, Table 1 shows an increased value, which suggested the formation of a homogenous MAP/TEOS film on the surface of the as-received substrate, with lower wettability and more protective character. In comparison with the MAP/TEOS coated as-received substrate, the MAP/TEOS coated ground substrate showed less noble, and negative potential values, indicating a film with a less protective character.

The MAP/TEOS film deposited on the as-received substrate exhibited the noblest potential values (Figure 4) that were close to that of the uncoated as-received substrate, pointing out that the MAP/TEOS film preserved the protective character against corrosion of the as-received substrate. This result is in concordance with FEGSEM and contact angle results. The analysis of FEGSEM image shown in Figure 2(d) indicated that the MAP/TEOS film did not have any cracks and, concerning the contact angle, Table 1 shows an increased value, which suggested the formation of a homogenous MAP/TEOS film on the surface of the as-received substrate, with lower wettability and more protective character. In comparison with the MAP/TEOS coated as-received substrate, the MAP/TEOS coated ground substrate showed less noble, and negative potential values, indicating a film with a less protective character.

The MAP/TEOS/F18 film deposited on the as-received substrate also exhibited nobler, and positive potential values (Figure 4) as compared with the film on the coated ground substrate. However, the curve of the TS/BCF18 sample trended to less cathodic values from the first 1,250 s of the test. This behavior can be related to the cracks observed in the FEGSEM micrographs [Figure 2(e)], which developed preferential paths for the electrolyte permeability, thus making possible the local contact of the metallic surface with the corrosive medium (Mohammadloo et al., 2012). However, from 1,250 s, the OCP reached a steady-state and kept constant up to the end of the corrosion test. It is important to highlight that the application of 
Bioglass 18 in the MAP/TEOS film on the ground substrate rendered the surface less anodic and more protective since the open circuit potential values for this system were closer to those of the uncoated and coated as-received substrates.

Figure 5 presents the cell morphology of the film/substrate systems, from which it is possible to evaluate the morphological behavior of the MG-63 cells at one day contact time with the TS/B [Figure 5(a)], TS/BC [Figure 5(b)] and TS/BCF18 [Figure 5(c)] samples. Microscopic analysis helps distinguish the cell morphology and viability after the bioglass incorporation into the silane film. Cell growth occurred under all tested conditions. The TS/B sample exhibited cells with defined cytoplasm, indicating that the surface provided favorable conditions to cell adaptation. For the TS/BC and TS/BCF18 systems, the presence of various rounded nuclei and scarce extracellular matrix was observed relative to the TS/B sample. This morphology could be related to the adaptation step of the cells to the MAP/TEOS and MAP/TEOS/F18 films (Huang et al., 2016; Wennerberg \& Albrektsson, 2009).

On day 7, most of the surface was covered by cell cytoskeleton protrusions, indicating that the samples provided cell anchoring (Huang et al., 2016; Wennerberg \& Albrektsson, 2009). Adhered cells exhibited different morphologies, having a more elongated and starred shape, characteristic of viable and adapted cells (Huang et al., 2016). The lamellipodia and filopodia are protuberant extensions originating from the membrane of a cell. Lamellipodia is a membrane extension with several filopodia joined by actin, and the actin is a protein that forms microfilaments. It is due to the presence of actin that the filopodia become sealed as in a sheet-like with network structure. According to Mattila and Lappalainen (2008), the difference between lamellipodia and filopodia is due to the size of the extension. The filopodia are primary structures finger-like that extend up to $0.3 \mu \mathrm{m}$ and act as a function of mobility and cell spreading. The lamellipodia are structures containing sealed filopodia by the presence of actin.

At the TS/B surface [Figure 5(a)], the cells developed into more rounded structures and spread longitudinally. For the TS/BC sample [Figure 5(b)], the cells elongated as well as the cells seeded on the system TS/BCF18 surface, Figure 5(c). Generally, MG-63 cells tend to be rounded on the metallic surface and elongated on the film-containing surface (Huang et al., 2016). In this way, the protrusion heights and the surface nano roughness may specifically modulate cell morphology. This fact relates to membrane projections, which allow the cells to peruse the surface to find suitable adhesion spots (Dalby et al., 2014; Gittens et al., 2011; Huang et al., 2016; Olivares-Navarrete et al., 2015; Zareidoost et al., 2012). 
Research, Society and Development, v. 10, n. 6, e23310615308, 2021

(CC BY 4.0) | ISSN 2525-3409 | DOI: http://dx.doi.org/10.33448/rsd-v10i6.15308

Figure 5. FEGSEM micrographs at 1 day and 7 days contact with MG-83 cells.
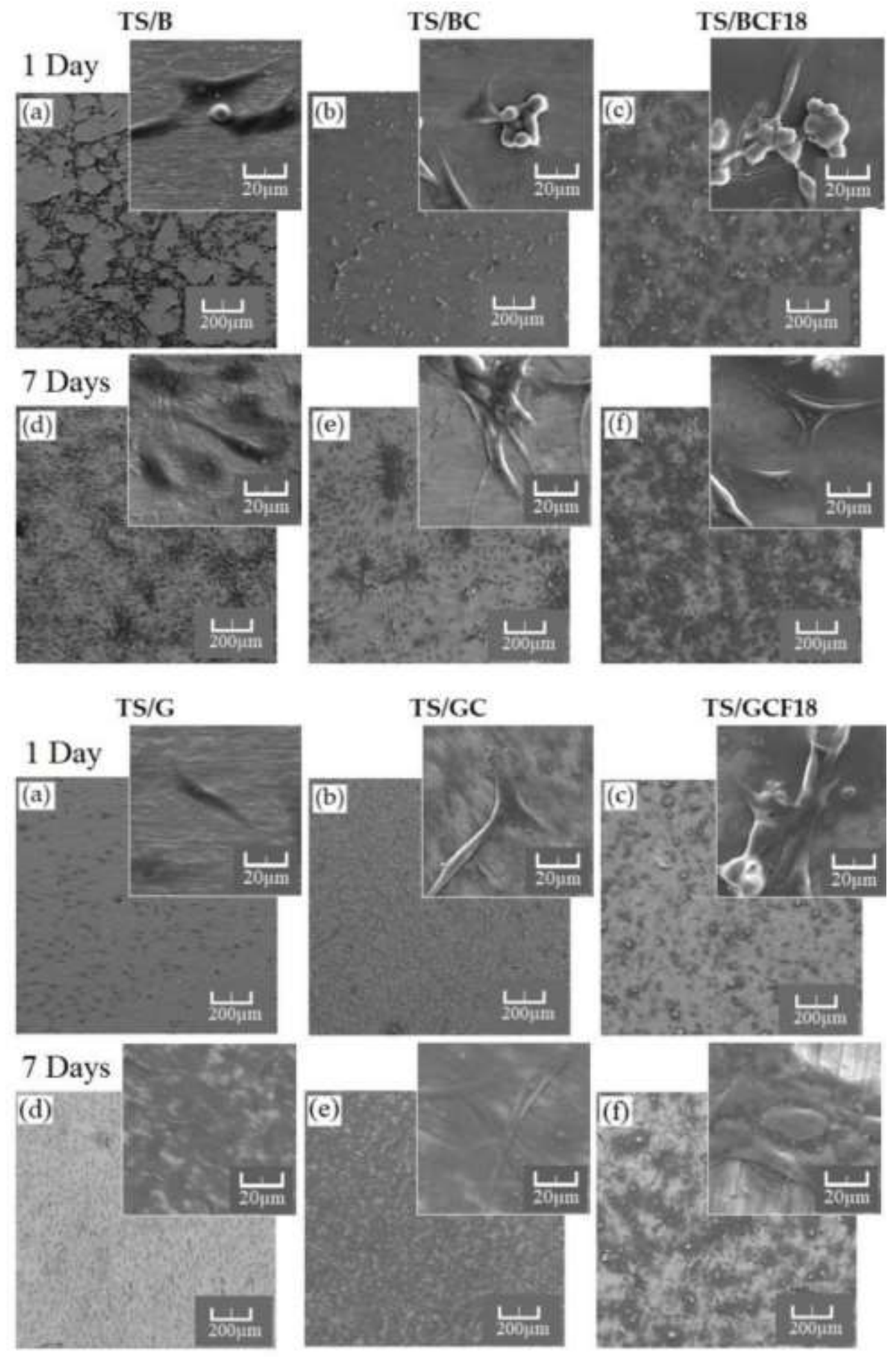

Source: Authors.

Roughness and the nanoscale topography influenced cell interaction since the dimension of the cell structure, such as the cytoskeleton and transmembrane proteins are of nanometric scale (Biggs et al., 2010; Gittens et al., 2011; Huang et al., 2016; Olivares-Navarrete et al., 2015; Zareidoost et al., 2012). 
For the ground substrate, the morphological behavior of MG-63 cells in 1 day [Figure 5(d)] was similar to that observed in the same period for the as-received samples group. On the seventh day, the morphology of the adhered cells cytoplasm seems starred and elongated, and the cells appear longitudinally spread throughout the whole surface of the samples. Through the TS/G sample micrograph [Figure 5(d)], a huge amount of extracellular matrix can be observed, as defined by darker regions, suggesting that the cells are at the surface adaptation step. Cells cultivated at the TS/GCF18 surface exhibited less elongated morphology than the TS/G and TS/GC samples, which was probably related to increased cell density, which limited the ground for extracellular matrix elongation (Huang et al., 2016).

Besides roughness, surface hydrophilia is a further decisive factor for determining adhesion and cell proliferation, since hydrophilic surfaces provide better interactions with biological fluids, protein absorption, cells, and tissues, favoring cell adhesion and dissemination (Malaval et al., 1999). Under this point of view, all the tested systems are hydrophilic, with the TS/BCF18 and TS/GCF18 samples showing lower contact angles. Thus, the higher wettability of these two film/substrate systems, as corroborated in the literature, improved cellular growth since they exhibited higher cell density after seven days test [Figure 5(c,f)].

Adding further comments concerning the effect of Bioglass F18 incorporation into the MAP/TEOS film deposited on both the as-received and ground samples, it can be observed in Figure 5(c,f) that the cells had affinity by bioglass particles since the higher cell density regions are located close to or on the particles. The cell membrane protrusions are elongated on the Bioglass F18 particles, indicating that the cell adapted itself and identified Bioglass F18 as an integral part of its biological system.

Viability cell results were expressed in percentage. The negative control absorbance represented $100 \%$ viability, and the values for treated cells were calculated as percentages of the control. Figure 6 shows the viability percentages obtained for each sample, besides the positive and negative controls. The cell viability percent was obtained for the periods of one and seven contact days of the samples with the MG-63 cells.

For samples related to one contact day with the MG-63 cells, cell viability results indicated no statistical difference among the samples and the negative control. Conversely, there was a statistical difference with the positive control. On the seventh day, for the TS/B and TS/BCF18 samples, there was cell death as compared with the negative control group. The coated sample (TS/BC) did not show any statistical difference as compared with the negative control. The positive control exhibited significant cell death. For the ground substrates, the same behavior remained for the 7-day period, for which the TS/G, TS/GC, and TS/GCF18 samples were statistically the same as the negative control and statistically different from the positive control. Regarding the positive control, the fall in percent value was attributed to the presence of the DMEM medium, characterized as harsh, causing cell death.

From Figure 6, it is important to highlight that the grinding process (TS/G, TS/GC, and TS/GCF18 samples) did not show any significant difference among the periods but provided higher percent values of cell viability than those of the asreceived samples. 
Figure 6. Cell viability evaluated after one day (a) and after seven days (b) of MG-63 cells in contact with all samples. Results are presented as the average and standard error. Letters above the bars correspond to comparisons of the several groups with the control group; different letters mean significant statistical differences among groups.
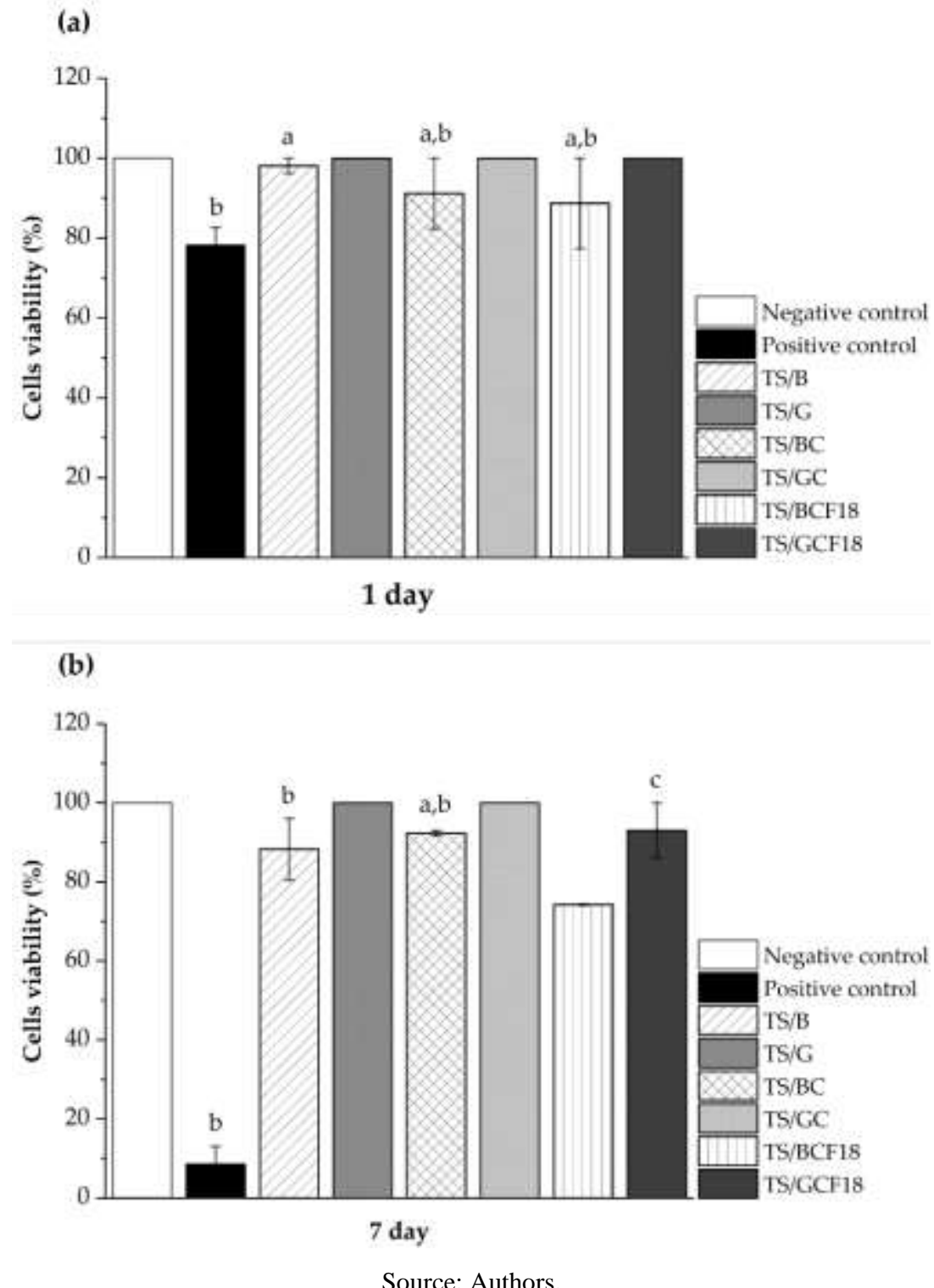

Figure 7(a) shows the cytotoxicity analysis of the substrates and the MAP/TEOS and MAP/TEOS/F18 film/substrate systems. Cytotoxic analysis by fluorescence microscopy technique makes it possible to assess the harmful action of a substance or coating concerning the cells of interest. Cells in apoptosis (orange color) were counted with the aid of a fluorescence microscope at $100 \times$ magnification. Green-colored cells characterize viable cells. Increased cellular proliferative activity was confirmed, given the higher intensity of the viable (green) cells during the periods for all the studied conditions. The number of cells in apoptosis (orange) was considered as minimal, not significant, as compared with the intensity of viable cells. These results indicate that the samples surfaces did not present any cytotoxic property. 
Figure 7. (a) Fluorescence microscopy for detecting living and death cells on the surface for all the tested conditions. (b) Counting of viable cells, in initial apoptosis and final apoptosis/necrosis for all the systems at 7 contact days with MG-63 cells.

(a)
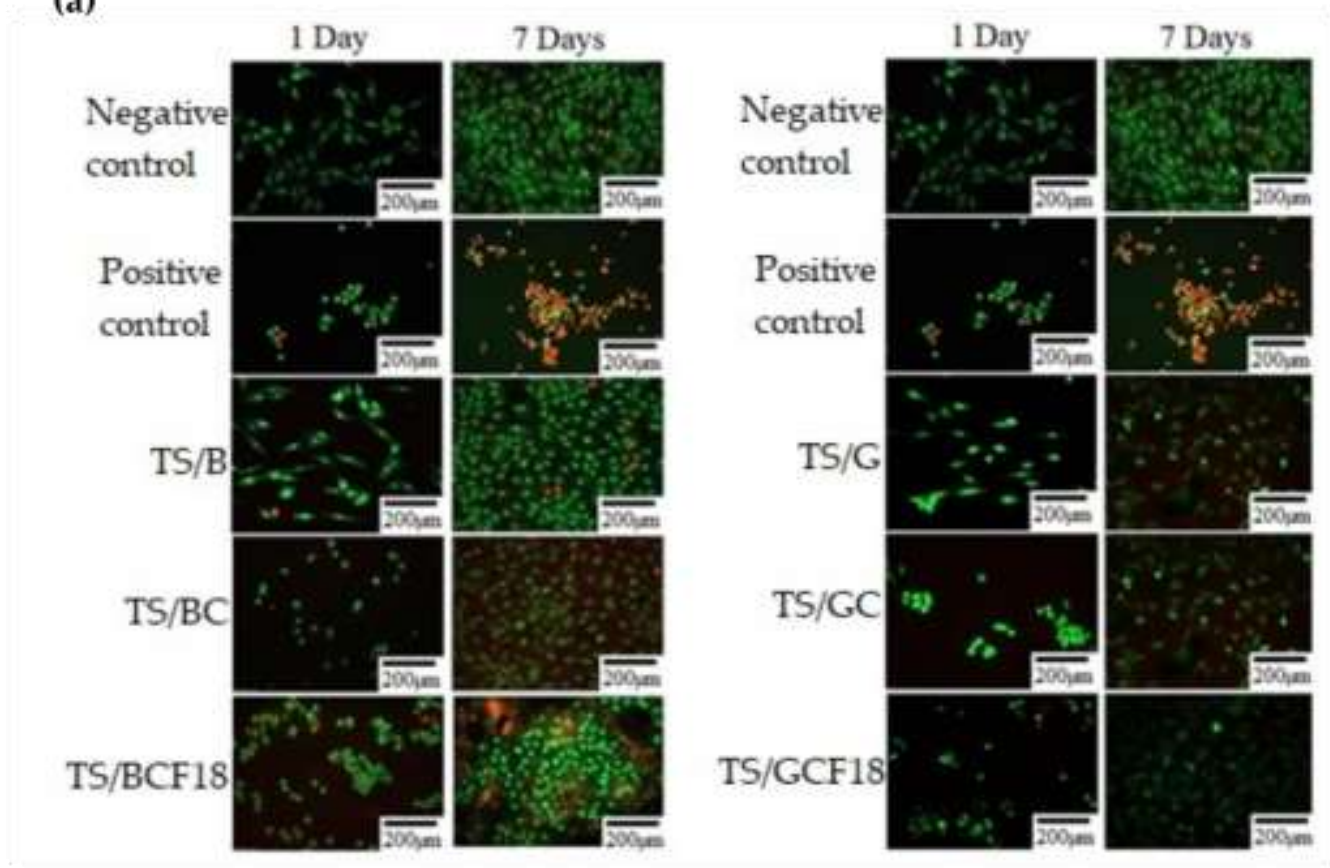

(b)
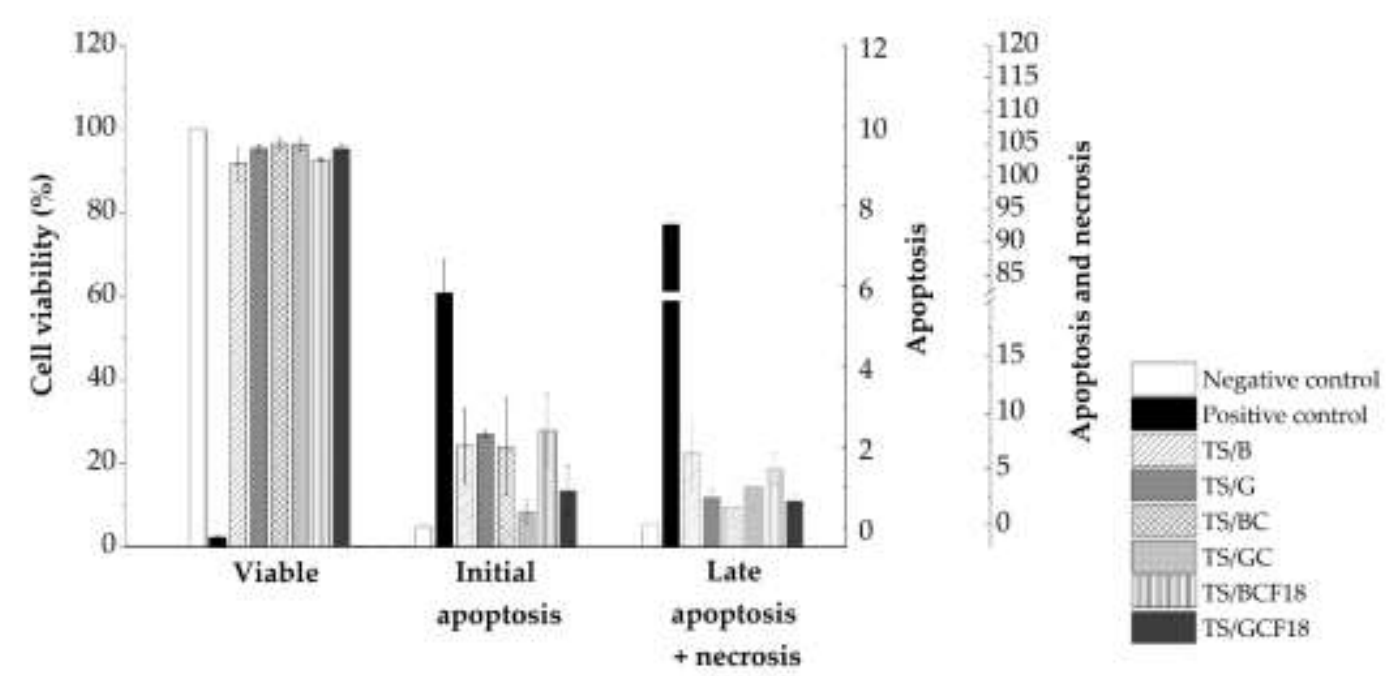

Source: Authors.

Results obtained for seven days are qualitatively displayed in Figure 7(b). It can be observed that there was a statistically significant difference by comparing the TS/B, TS/BC, TS/BCF18 samples with the positive control for the initial apoptosis and final apoptosis/necrosis, corroborating the non-cytotoxicity of the samples. This behavior was expected since few cells in apoptosis were observed in Figure 7(a). Moreover, there were no statistically significant differences among the TS/G, TS/GC, and TS/GCF18 samples (uncoated and coated ground substrates) for the final apoptosis/necrosis.

The number of cells in final apoptosis/necrosis for the TS/G, TS/GC, and TS/GCF18 samples (after grinding) was lower than those of the TS/B, TS/BC, and TS/BCF18 samples (as-received), which is possibly related to the topography and roughness introduced by the grinding process. The higher asperity heights of the ground samples may have promoted viability and cell proliferation (Biggs et al., 2010; Gittens et al., 2011; Huang et al., 2016; Malaval et al., 1999; Olivares-Navarrete et al., 2015; Zareidoost et al., 2012). 


\section{Conclusions}

The surface of a Ti-6Al-4V alloy was modified by a grinding process and MAP/TEOS coating. Besides roughness, the effect of F18 bioglass particles added to the film on surface characteristics was also investigated. Substrates and film/substrates systems were characterized by a variety of techniques to evaluate the roughness, wettability, and chemistry of the surfaces, the film adhesion to the substrate, the formation of a passive film, as well as the behavior of osteoblastic cells (viability, spreading, proliferation and cytotoxicity). The results show that surface roughness directly influences the adhesion of the silane-based film to Ti-6Al-4V alloy. Coated ground substrates (TS/GC and TS/GCF18 sample) exhibit the lowest percent values of the film area removed. This corroborates that roughness promotes anchorage spots for better film adhesion to the substrate. Coating the as-received titanium alloy with bioglass-free and bioglass-containing silane-based films provides the formation of a protective surface layer against corrosion in the SBF medium. The as-received titanium alloy substrate covered with MAP/TEOS film presents the highest open circuit potential. Although the grinding process causes a detrimental effect in open circuit potential due to the removal of the protective surface layer, nobler potential values can be reestablished to a maximum level by coating the ground substrate with an F18 bioglass-containing MAP/TEOS film. Increasing amplitude roughness parameters, $R a, R z$, and $R t$, of the titanium alloy surface by grinding process and by coating the surface with MAP/TEOS and MAP/TEOS/F18 films promote higher viability and better adaptation of cells. The incorporation of F18 bioglass particles into the MAP/TEOS films enhances surface wettability regardless of the substrate roughness. The higher cellular density near bioglass particles sites indicates the affinity of cells for F18 Bioglass particles. Furthermore, the results suggest that surface chemistry modification by silane-based coatings and, especially, the incorporation of bioglass particles dominates surface wettability, with the substrate roughness acting as a secondary factor. However, concerning film adhesion, protective properties against corrosion, and cytotoxicity of osteoblastic cells, roughness plays an important role. Thus, to achieve better film adhesion to the substrate, enhanced wettability, good protective properties against corrosion, good cell adaptation, and low cytotoxicity, the use of both the grinding process and the application of an F18 bioglass-containing MAP/TEOS coating are suggested among the studied film/substrate systems. The authors suggest as future research, bioglass mixed with other materials or different forms of deposition to improve biocompatibility.

\section{Acknowledgments}

This work was supported by the National Council for Scientific and Technological Development $-\mathrm{CNPq}$ (Productivity Research PQ2 scholarship) and by the Coordination for the Improvement of Higher Education Personnel CAPES by through the Master's Program in Process and Technology Engineering. The authors would like to acknowledge the provision of the laboratory facilities by both the Laboratório Central de Microscopia, Professor Israel Baumvol, (LCMIC), and the Laboratory of Genomics, Proteomics and DNA Repair from University of Caxias do Sul (UCS), Brazil.

\section{References}

Ahmed, A. A., Mhaede, M., Wollmann, M., \& Wagner, L. (2016). Effect of micro shot peening on the mechanical properties and corrosion behavior of two microstructure Ti-6Al-4V alloy. Applied Surface Science, 363, 50-58. https://doi.org/10.1016/j.apsusc.2015.12.019

Andrade, A. D., Marinho, C. F., Barcelos, M., Zorzal, M. B., \& Conz, M. B. (2007). Bone biology: the review of literature. 4(6), 659-662.

Asri, R. I. M., Harun, W. S. W., Samykano, M., Lah, N. A. C., Ghani, S. A. C., Tarlochan, F., \& Raza, M. R. (2017). Corrosion and surface modification on biocompatible metals: A review. Materials Science and Engineering C, 77, 1261-1274. https://doi.org/10.1016/j.msec.2017.04.102

Aydınoğlu, A., \& Yoruç, A. B. H. (2017). Effects of silane-modified fillers on properties of dental composite resin. Materials Science and Engineering C, 79, 382-389. https://doi.org/10.1016/j.msec.2017.04.151

Baxter, L. C., Frauchiger, V., Textor, M., Ap Gwynn, I., Richards, R. G., Bongrand, P., \& Brunette, D. (2002). Fibroblast and osteoblast adhesion and morphology on calcium phosphatesurfaces. European Cells and Materials, 4(0), 1-17. https://doi.org/10.22203/eCM.v004a01 
Biggs, M. J. P., Richards, R. G., \& Dalby, M. J. (2010). Nanotopographical modification: A regulator of cellular function through focal adhesions. Nanomedicine: Nanotechnology, Biology, and Medicine, 6(5), 619-633. https://doi.org/10.1016/j.nano.2010.01.009

Certhoux, E., Ansart, F., Turq, V., Bonino, J. P., Sobrino, J. M., Garcia, J., \& Reby, J. (2013). New sol-gel formulations to increase the barrier effect of a protective coating against the corrosion of steels. Progress in Organic Coatings, 76(1), 165-172. https://doi.org/10.1016/j.porgcoat.2012.09.002

Chen, Q., \& Thouas, G. A. (2015). Metallic implant biomaterials. Materials Science and Engineering R: Reports, 87, 1-57. https://doi.org/10.1016/j.mser.2014.10.001

Chiu, K. Y., Wong, M. H., Cheng, F. T., \& Man, H. C. (2007). Characterization and corrosion studies of titania-coated NiTi prepared by sol-gel technique and steam crystallization. Applied Surface Science, 253(16), 6762-6768. https://doi.org/10.1016/j.apsusc.2007.01.121

Chowdhury, S. S., Pandey, P. R., Kumar, R., \& Roy, S. (2017). Effect of shape of protrusions and roughness on the hydrophilicity of a surface. Chemical Physics Letters, 685, 34-39. https://doi.org/10.1016/j.cplett.2017.07.015

Cremasco, A., Messias, A. D., Esposito, A. R., Duek, E. A. D. R., \& Caram, R. (2011). Effects of alloying elements on the cytotoxic response of titanium alloys. Materials Science and Engineering C, 31(5), 833-839. https://doi.org/10.1016/j.msec.2010.12.013

Dalby, M. J., Gadegaard, N., \& Oreffo, R. O. C. (2014). Harnessing nanotopography and integrin-matrix interactions to influence stem cell fate. Nature Materials, 13(6), 558-569. https://doi.org/10.1038/nmat3980

De Graeve, I., Vereecken, J., Franquet, A., Van Schaftinghen, T., \& Terryn, H. (2007). Silane coating of metal substrates: Complementary use of electrochemical, optical and thermal analysis for the evaluation of film properties. Progress in Organic Coatings, 59(3), 224-229. https://doi.org/10.1016/j.porgcoat.2006.09.006

El-Ghannam, A., \& Ducheyne, P. (2017). 1.9 Bioactive Ceramics $\longleftarrow$. In P. Ducheyne (Ed.), Comprehensive Biomaterials II (pp. 204-234). Elsevier. https://doi.org/https://doi.org/10.1016/B978-0-12-803581-8.10169-9

Fu, T., Wu, X. M., Wu, F., Luo, M., Dong, B. H., \& Ji, Y. (2012). Surface modification of NiTi alloy by sol-gel derived porous TiO2 film. Transactions of Nonferrous Metals Society of China (English Edition), 22(7), 1661-1666. https://doi.org/10.1016/S1003-6326(11)61370-8

Gadelmawla, E. S., Koura, M. M., Maksoud, T. M. A., Elewa, I. M., \& Soliman, H. H. (2002). Roughness parameters. Journal of Materials Processing Technology, 123(1), 133-145. https://doi.org/10.1016/S0924-0136(02)00060-2

Gittens, R. A., McLachlan, T., Olivares-Navarrete, R., Cai, Y., Berner, S., Tannenbaum, R., Schwartz, Z., Sandhage, K. H., \& Boyan, B. D. (2011). The effects of combined micron-/submicron-scale surface roughness and nanoscale features on cell proliferation and differentiation. Biomaterials, 32(13), 33953403. https://doi.org/10.1016/j.biomaterials.2011.01.029

Hallab, N. J., Jacobs, J. J., \& Katz, J. L. (2004). Orthopedic Applications. In B. D. Ratner, A. S. Hoffman, F. J. Schoen, \& J. E. Lemons (Eds.), Biomaterials Science: An Introduction to Materials in Medicine (2nd ed., pp. 527-555). Elsevier Academic Press.

Harada, R., Takemoto, S., Kinoshita, H., Yoshinari, M., \& Kawada, E. (2016). Influence of sulfide concentration on the corrosion behavior of titanium in a simulated oral environment. Materials Science and Engineering C, 62, 268-273. https://doi.org/10.1016/j.msec.2016.01.065

Hotchkiss, K. M., Reddy, G. B., Hyzy, S. L., Schwartz, Z., Boyan, B. D., \& Olivares-Navarrete, R. (2016). Titanium surface characteristics, including topography and wettability, alter macrophage activation. Acta Biomaterialia, 31, 425-434. https://doi.org/10.1016/j.actbio.2015.12.003

Huang, Q., Elkhooly, T. A., Liu, X., Zhang, R., Yang, X., Shen, Z., \& Feng, Q. (2016). Effects of hierarchical micro/nano-topographies on the morphology, proliferation and differentiation of osteoblast-like cells. Colloids and Surfaces B: Biointerfaces, 145, 37-45. https://doi.org/10.1016/j.colsurfb.2016.04.031

Ibrahim, M. Z., Sarhan, A. A. D., Yusuf, F., \& Hamdi, M. (2017). Biomedical materials and techniques to improve the tribological, mechanical and biomedical properties of orthopedic implants - A review article. Journal of Alloys and Compounds, 714, 636-667. https://doi.org/10.1016/j.jallcom.2017.04.231

Köche, J. C. (2011). Fundamentos de metodologia científica: Teoria da ciência e iniciação à pesquisa. Vozes.

Kokubo, T., \& Takadama, H. (2006). How useful is SBF in predicting in vivo bone bioactivity? Biomaterials, 27(15), 2907-2915. https://doi.org/10.1016/j.biomaterials.2006.01.017

Kota, A. K., Kwon, G., \& Tuteja, A. (2014). The design and applications of superomniphobic surfaces. NPG Asia Materials, 6(6), 1-16. https://doi.org/10.1038/am.2014.34

Kunst, S. R., Cardoso, H. R. P., Beltrami, L. V. R., Oliveira, C. T., Menezes, T. L., Ferreira, J. Z., \& Malfatti, C. de F. (2015). New Sol-gel Formulations to Increase the Barrier Effect of a Protective Coating Against the Corrosion and Wear of Galvanized Steel. Materials Research, 18(1), 138-150. https://doi.org/10.1590/1516-1439.288914

Kunst, S. R., Korb, M. de A., Menezes, T. L., Oliveira, C. T., Malfatti, C. de F., \& Tessaro, G. (2013). Influence of the curing process of the hybrid films on the performance of coatings obtained by epoxy painting. Metallurgy and Materials, 66(3), 309-316. https://doi.org/10.1590/S0370-44672013000300007

Kurella, A., \& Dahotre, N. B. (2005). Surface modification for bioimplants: The role of laser surface engineering. In Journal of Biomaterials Applications (Vol. 20, Issue 1). https://doi.org/10.1177/0885328205052974

Kuscer, D., Kovač, J., Kosec, M., \& Andriesen, R. (2008). The effect of the valence state of titanium ions on the hydrophilicity of ceramics in the titaniumoxygen system. Journal of the European Ceramic Society, 28(3), 577-584. https://doi.org/10.1016/j.jeurceramsoc.2007.07.014 
Liang, J., Hu, Y., Wu, Y., \& Chen, H. (2014). Facile formation of superhydrophobic silica-based surface on aluminum substrate with tetraethylorthosilicate and vinyltriethoxysilane as co-precursor and its corrosion resistant performance in corrosive NaCl aqueous solution. Surface and Coatings Technology, 240 , 145-153. https://doi.org/10.1016/j.surfcoat.2013.12.028

Malaval, L., Liu, F., Roche, P., \& Aubin, J. E. (1999). Kinetics of osteoprogenitor proliferation and osteoblast differentiation in vitro. Journal of Cellular Biochemistry, 74(4), 616-627. https://doi.org/10.1002/(SICI)1097-4644(19990915)74:4<616::AID-JCB11>3.0.CO;2-Q

Mathew, M. T., Abbey, S., Hallab, N. J., Hall, D. J., Sukotjo, C., \& Wimmer, M. A. (2012). Influence of pH on the tribocorrosion behavior of CpTi in the oral environment: Synergistic interactions of wear and corrosion. Journal of Biomedical Materials Research - Part B Applied Biomaterials, 100 B(6), 1662-1671. https://doi.org/10.1002/jbm.b.32735

Mattila, P. K., \& Lappalainen, P. (2008). Filopodia: Molecular architecture and cellular functions. Nature Reviews Molecular Cell Biology, 9(6), 446-454. https://doi.org/10.1038/nrm2406

Mohammadloo, H. E., Sarabi, A. A., Sabbagh Alvani, A. A., Sameie, H., \& Salimi, R. (2012). Nano-ceramic hexafluorozirconic acid based conversion thin film: Surface characterization and electrochemical study. Surface and Coatings Technology, 206(19-20), 4132-4139. https://doi.org/10.1016/j.surfcoat.2012.04.009

Murugan, N., Kavitha, L., Shinyjoy, E., Rajeswari, D., Vimala, K., Kannan, S., \& Gopi, D. (2015). Smart rose flower like bioceramic/metal oxide dual layer coating with enhanced anti-bacterial, anti-cancer, anti-corrosive and biocompatible properties for improved orthopedic applications. RSC Advances, 5(104), 85831-85844. https://doi.org/10.1039/c5ra17747b

Olivares-Navarrete, R., Rodil, S. E., Hyzy, S. L., Dunn, G. R., Almaguer-Flores, A., Schwartz, Z., \& Boyan, B. D. (2015). Role of integrin subunits in mesenchymal stem cell differentiation and osteoblast maturation on graphitic carbon-coated microstructured surfaces. Biomaterials, 51, 69-79. https://doi.org/10.1016/j.biomaterials.2015.01.035

Owens, G. J., Singh, R. K., Foroutan, F., Alqaysi, M., Han, C.-M., Mahapatra, C., Kim, H.-W., \& Knowles, J. C. (2016). Sol-gel based materials for biomedical applications. Progress in Materials Science, 77, 1-79. https://doi.org/10.1016/j.pmatsci.2015.12.001

Pandiyaraj, K. N., Selvarajan, V., Rhee, Y. H., Kim, H. W., \& Pavese, M. (2010). Effect of dc glow discharge plasma treatment on PET/TiO2 thin film surfaces for enhancement of bioactivity. Colloids and Surfaces B: Biointerfaces, 79(1), 53-60. https://doi.org/10.1016/j.colsurfb.2010.03.023

Pereira, A., Shitsuka, D. M., Parreira, F. J., \& Shitsuka, R. (2018). Metodologia da Pesquisa Científica. Universidade de Santa Maria.

Pires, A. L. R., Bierhalz, A. C. K., \& Moraes, A. M. (2015). Biomateriais: tipos, aplicações e mercado. Química Nova, 38(7), 957-971. https://doi.org/10.5935/0100-4042.20150094

Punt, I. M., Visser, V. M., Van Rhijn, L. W., Kurtz, S. M., Antonis, J., Schurink, G. W. H., \& Van Ooij, A. (2008). Complications and reoperations of the SB Charité lumbar disc prosthesis: Experience in 75 patients. European Spine Journal, 17(1), 36-43. https://doi.org/10.1007/s00586-007-0506-8

Quéré, D. (2008). Wetting and Roughness. Annual Review of Materials Research, 38(1), 71-99. https://doi.org/10.1146/annurev.matsci.38.060407.132434

Rasouli, R., Barhoum, A., \& Uludag, H. (2018). A review of nanostructured surfaces and materials for dental implants: Surface coating, patterning and functionalization for improved performance. Biomaterials Science, 6(6), 1312-1338. https://doi.org/10.1039/c8bm00021b

Rodríguez-Cano, A., Cintas, P., Fernández-Calderón, M. C., Pacha-Olivenza, M. ángel, Crespo, L., Saldaña, L., Vilaboa, N., González-Martín, M. L., \& Babiano, R. (2013). Controlled silanization-amination reactions on the Ti6Al4V surface for biomedical applications. Colloids and Surfaces B: Biointerfaces, 106, 248-257. https://doi.org/10.1016/j.colsurfb.2013.01.034

Romagnoli, C., D’Asta, F., \& Brandi, M. L. (2013). Drug delivery using composite scaffolds in the context of bone tissue engineering. Clinical Cases in Mineral and Bone Metabolism, 10(3), 155-161. https://doi.org/10.11138/ccmbm/2013.10.3.155

Romano, A. P., Fedel, M., Deflorian, F., \& Olivier, M. G. (2011). Silane sol-gel film as pretreatment for improvement of barrier properties and filiform corrosion resistance of 6016 aluminium alloy covered by cataphoretic coating. Progress in Organic Coatings, 72(4), 695-702. https://doi.org/10.1016/j.porgcoat.2011.07.012

Rosa, M. B., Albrektsson, T., Francischone, C. E., Schwartz Filho, H. O., \& Wennerberg, A. (2013). Micrometric characterization of the implant surfaces from the five largest companies in Brazil, the second largest worldwide implant mrket. The International Journal of Oral \& Maxillofacial Implants, 28(2), 358-365. https://doi.org/10.11607/jomi.2791

Sakai, R. T., Di Da Cruz, F. M. L., De Melo, H. G., Benedetti, A. V., Santilli, C. V., \& Suegama, P. H. (2012). Electrochemical study of TEOS, TEOS/MPTS, MPTS/MMA and TEOS/MPTS/MMA films on tin coated steel in $3.5 \% \mathrm{NaCl}$ solution. Progress in Organic Coatings, $74(2)$, 288-301. https://doi.org/10.1016/j.porgcoat.2012.01.001

Salvador, D. G., Marcolin, P., Beltrami, L. V. R., Brandalise, R. N., \& Kunst, S. R. (2017). Influence of the pretreatment and curing of alkoxysilanes on the protection of the titanium-aluminum-vanadium alloy. Journal of Applied Polymer Science (Online). https://doi.org/10.1002/app.45470

Salvador, D. G., Marcolin, P., Beltrami, L. V. R., Brandalise, R. N., \& Kunst, S. R. (2018). Development of Alkoxide Precursors-Based Hybrid Coatings on Ti-6Al-4V Alloy for Biomedical Applications: Influence of $\mathrm{pH}$ of Sol. Journal of Materials Engineering and Performance, 27(6), 2863-2874. https://doi.org/10.1007/s11665-018-3368-9

Savaris, M., Santos, V. dos, \& Brandalise, R. N. (2016). Influence of different sterilization processes on the properties of commercial poly(lactic acid). Materials Science and Engineering C, 69, 661-667. https://doi.org/10.1016/j.msec.2016.07.031 
Sepulveda, P., Jones, J. R., \& Hench, L. L. (2002). In vitro dissolution of melt-derived 45 S5 and sol-gel derived 58S bioactive glasses. Journal of Biomedical Materials Research, 61(2), 301-311. https://doi.org/10.1002/jbm.10207

Shoucheng, C., Guo, Y., Liu, R., Wu, S., Fang, J., Huang, B., Li, Z., Chen, Z., \& Chen, Z. (2018). Tuning surface properties of bone biomaterials to manipulate osteoblastic cell adhesion and the signaling pathways for the enhancement of early osseointegration. Colloids and Surfaces B: Biointerfaces, 164, 58-69. https://doi.org/10.1016/j.colsurfb.2018.01.022

Silva-Bermudez, P., \& Rodil, S. E. (2013). An overview of protein adsorption on metal oxide coatings for biomedical implants. Surface and Coatings Technology, 233, 147-158. https://doi.org/10.1016/j.surfcoat.2013.04.028

Sjöström, T., Brydone, A. S., Meek, R. D., Dalby, M. J., Su, B., \& Mcnamara, L. E. (2013). Titanium nanofeaturing for enhanced bioactivity of implanted orthopedic and dental devices. Nanomedicine, 8(1), 89-104. https://doi.org/10.2217/nnm.12.177

Slepička, P., Michaljaničová, I., Rimpelová, S., \& Švorčík, V. (2017). Surface roughness in action - Cells in opposition. Materials Science and Engineering C, 76, 818-826. https://doi.org/10.1016/j.msec.2017.03.061

Su, Y., Luo, C., Zhang, Z., Hermawan, H., Zhu, D., Huang, J., Liang, Y., Li, G., \& Ren, L. (2018). Bioinspired surface functionalization of metallic biomaterials. Journal of the Mechanical Behavior of Biomedical Materials, 77(January 2017), 90-105. https://doi.org/10.1016/j.jmbbm.2017.08.035

Tengvall, P., \& Lundström, I. (1992). Physico-chemical considerations of titanium as a biomaterial. Clinical Materials, 9, 115-134.

van Ooij, W. J., Zhu, D., Stacy, M., Seth, A., Mugada, T., Gandhi, J., \& Puomi, P. (2005). Corrosion protection properties of organofunctional silanes - An overview. Tsinghua Science and Technology, 10(6), 639-664. https://doi.org/10.1016/S1007-0214(05)70134-6

Veronesi, F., Giavaresi, G., Fini, M., Longo, G., Ioannidu, C. A., Scotto d'Abusco, A., Superti, F., Panzini, G., Misiano, C., Palattella, A., Selleri, P., Di Girolamo, N., Garbarino, V., Politi, L., \& Scandurra, R. (2017). Osseointegration is improved by coating titanium implants with a nanostructured thin film with titanium carbide and titanium oxides clustered around graphitic carbon. Materials Science and Engineering C, 70, 264-271. https://doi.org/10.1016/j.msec.2016.08.076

Wang, M., Wang, Y., Chen, Y., \& Gu, H. (2013). Improving endothelialization on 316L stainless steel through wettability controllable coating by sol-gel technology. Applied Surface Science, 268, 73-78. https://doi.org/10.1016/j.apsusc.2012.11.159

Wen-Cheng, C., \& Ko, C. L. (2013). Roughened titanium surfaces with silane and further RGD peptide modification in vitro. Materials Science and Engineering C, 33(5), 2713-2722. https://doi.org/10.1016/j.msec.2013.02.040

Wennerberg, A., \& Albrektsson, T. (2009). Effects of titanium surface topography on bone integration: A systematic review. Clinical Oral Implants Research, 20(SUPPL. 4), 172-184. https://doi.org/10.1111/j.1600-0501.2009.01775.x

Zanotto, E. D., Filho, O. P., \& Souza, M. T. (2013). Vitreous composition, bioactive vitreous fibres and fabrics, and articles. Patent WO 2015/021519. $P C T / B R 2014 / 000275$.

Zareidoost, A., Yousefpour, M., Ghasemi, B., \& Amanzadeh, A. (2012). The relationship of surface roughness and cell response of chemical surface modification of titanium. Journal of Materials Science: Materials in Medicine, 23(6), 1479-1488. https://doi.org/10.1007/s10856-012-4611-9

Zhao, B., Wang, H., Qiao, N., Wang, C., \& Hu, M. (2017). Corrosion resistance characteristics of a Ti-6Al-4V alloy scaffold that is fabricated by electron beam melting and selective laser melting for implantation in vivo. Materials Science and Engineering C, 70, 832-841. https://doi.org/10.1016/j.msec.2016.07.045 